\title{
Effectiveness of a self-myofascial conditioning programme on pain, depression, anxiety and sleep quality in people with Fibromyalgia
}

\section{Efectividad de un programa de autoacondicionamiento miofascial sobre el dolor, la depresión, la ansiedad y la calidad del sueño en personas con fibromialgia}

\section{Efetividade de um programa de auto-condicionamento miofascial na dor, depressão, ansiedade e qualidade do sono em pessoas com fibromialgia}

\author{
Ceca, D1, Pablos, A2, Elvira, L2, López-Hernández, L3, Ortega, A. L.4 \\ 1 Facultad de Educación. Universidad Internacional de Valencia; 2 Facultad de Ciencias de la Actividad \\ Física y el Deporte. Universidad Católica de Valencia San Vicente Mártir; 3 Facultad de Enfermería. \\ Universidad Católica de Valencia San Vicente Mártir; 4 Centro de lenguas. Universidad Católica de \\ Valencia San Vicente Mártir
}

\begin{abstract}
Self-myofascial release can facilitate the diminution or disappearance of the intense pain perceived by the nerve endings located in the myofascial tissue. According to some researchers, fibromyalgia (FM) can be directly related to the "central sensitization" theory. The present study aims to determine the effectiveness of the application of a self-myofascial conditioning programme on pain, depression, anxiety, and quality of sleep in people diagnosed with Fibromyalgia (FM). A single-blind randomized controlled trial with parallel-group study was designed. The sample, consisting of 66 people diagnosed with FM, was randomly assigned to intervention $(n=33$; age $=50.57 \pm 7.14)$ and control groups $(\mathrm{n}=33$; age $=57.4 \pm 4.52)$. Subjects in the intervention group took part in a self-myofascial conditioning programme, which consisted of 40 sessions of 50 minutes each. Pre and post-intervention measurements were taken. Results were obtained by a $2 \times 2$ ANOVA for repeated measures with two factors (time and group). Results show that, after completing the programme, subjects in the intervention group had seen a significant decrease in general pain $\left(P<0.01 ; \eta_{2 p}=0.197\right)$, level of depression $\left(P<0.05 ; \eta_{2 p}=0.128\right)$, state $\left(P<0.01 ; \eta_{2 p}=0.204\right)$ and trait anxiety $\left(P<0.01 ; \eta_{2 p}=0.174\right)$, as well as three subscales related to the quality of sleep, such as "sleep subjective quality" $\left(P<0.05 ; \eta_{2}=0.144\right)$, "habitual sleep efficiency" $\left(P<0.05 ; \eta_{2 p}=0.129\right)$ and "daily dysfunction" $(P<$ $\left.0.001 ; \eta_{2 p}=0.277\right)$. These results indicate that participating in a self-myofascial conditioning programme regularly and under the control of a physical education and sport professional can affect patients with FM positively both physically and psychologically.
\end{abstract}

Keywords: physical activity; foam roller; quality of life; fascia.

RESUMEN 


\section{Ceca et al.}

La autoliberación miofascial puede facilitar la disminución o desaparición del dolor intenso percibido por las terminaciones nerviosas localizadas en el tejido miofascial. Según algunos investigadores, la fibromialgia (FM) puede estar directamente relacionado con la teoría de la "sensibilización central". El presente estudio tiene como objetivo determinar la efectividad de la aplicación de un programa de autoacondicionamiento miofascial sobre el dolor, la depresión, la ansiedad y la calidad del sueño en personas diagnosticadas con fibromialgia (FM). Se diseñó un ensayo aleatorizado controlado, simple ciego, con grupos paralelos. La muestra, compuesta por 66 personas con diagnóstico de fibromialgia, se asignó al azar a los grupos de intervención $(\mathrm{n}=33$; edad $=50.57 \pm 7.14)$ y control ( $\mathrm{n}$ $=33$; edad $=57.4 \pm 4.52$ ). Los sujetos del grupo intervención participaron en un programa de autoacondicionamiento miofascial compuesto por un total de 40 sesiones de 50 minutos cada una de ellas. Se tomaron medidas pre y post intervención. Los resultados se obtuvieron mediante un ANOVA 2x2 de medidas repetidas con dos factores (tiempo y grupo). Los resultados muestran que, después de completar el programa, los sujetos del grupo intervención obtuvieron una disminución significativa en el dolor general $\left(P<0.01 ; \eta_{2} p=0.197\right)$, el nivel de depresión $(P<0.05$; $\left.\eta_{2 p}=0.128\right)$, la ansiedad-estado $\left(P<0.01 ; \eta_{2 p}=0.204\right)$ y rasgo $\left(P<0.01 ; \eta_{2 p}=0.174\right)$, así como en tres subescalas relacionadas con la calidad del sueño, como son la "calidad subjetiva del sueño" $\left(P<0.05 ; \eta_{2} p=0.144\right)$, la "eficiencia habitual del sueño" $\left(P<0.05 ; \eta_{2 p}=0.129\right)$ y la "disfunción diaria " $\left(P<0.001 ; \eta_{2 p}=0.277\right)$. Estos resultados indican que participar en un programa de autoacondicionamiento miofascial regularmente, bajo el control de un profesional de educación física y deporte, puede afectar positivamente a los pacientes con FM tanto física como psicológicamente.

Palabras clave: actividad física, foam roller, calidad de vida, fascia.

\section{RESUMO}

A auto-liberação miofascial pode facilitar a diminuição ou o desaparecimento da dor intensa percebida pelas terminações nervosas localizadas no tecido miofascial. Segundo alguns pesquisadores, a fibromialgia (FM) pode estar diretamente relacionada à teoria da "sensibilização central". O presente estudo tem como objetivo determinar a eficácia da aplicação de um programa de auto-condicionamento miofascial na dor, depressão, ansiedade e qualidade do sono em pessoas diagnosticadas com fibromialgia (FM). Realizouse un estudo aleatorizado e controlado, simplescego, com grupos paralelos. A amostra, composta por 66 pessoas com diagnóstico de fibromialgia, foi randomizada para os grupos intervenção $(n=33$; idade $=50.57 \pm 7.14)$ e controle $(n=33$; idade $=57.4 \pm 4.52)$. Os sujeitos do grupo de intervenção participaram de um programa de auto- condicionamento miofascial composto por um total de 40 sessões de 50 minutos cada. Medidas de intervenção pré e pós foram tomadas. Os resultados foram obtidos por meio de uma ANOVA 2x2 de medidas repetidas com dois fatores (tempo e grupo). Os resultados mostram que, após o término do programa, os sujeitos do grupo de intervenção obtiveram uma diminuição significativa na dor geral $(P<$ $\left.0.01 ; \eta_{2 p}=0.197\right)$, o nível de depressão $(P<0.05 ; \eta 2 p=0.128)$, estado de ansiedade $(P<0.01 ; \eta 2 p=0.204)$ e traço $(P<0.01 ; \eta 2 p=0.174)$, assim como em três subescalas relacionadas à qualidade do sono, como a "qualidade subjetiva do sono" $(P<0.05 ; \eta 2 p=0.144)$, a "eficiência habitual do sono" $(P<0.05 ; \eta 2 p=0.129)$ e "disfunção diária" $(P<$ $0.001 ; \eta 2 p=0.277)$. Esses resultados indicam que participar de um programa de auto-condicionamento miofascial regularmente, sob o controle de um profissional de educação física e esportes, pode afetar positivamente os pacientes com FM fisicamente e psicologicamente.

Palavras chave: actividade física, foam roller, qualidade de vida, fascia 


\section{Effects of a self-myofascial conditioning programme on fibromyalgia}

\section{INTRODUCTION}

Fibromyalgia (FM) is a disorder that affects from $0.7 \%$ to $10 \%$ of the people on the planet. In Spain, the prevalence of the disorder is estimated to be $2.37 \%$ of the population older than 20 years of age. This prevalence varies significantly by gender: $4.2 \%$ in women versus $0.2 \%$ in men (Cabo-Meseguer, CerdaOlmedo, \& Luis Trillo-Mata, 2017; Mas, Carmona, Valverde, Ribas, \& EPISER Study Group, 2008), being these data similar to those found in different European countries like Italy or Germany (Branco et al., 2010; Cabo-Meseguer et al., 2017).

In spite of this agreement, the aforementioned percentages are not the most relevant factor, but the fact that behind this scenario there are patients with highly varied clinical symptomatology. These patients can share a common clinical profile consisting of generalized pain, fatigue or poor-quality sleep (Crofford, 2016; Wolfe et al., 1990), or high stress levels, anxiety and depression (Bartkowska, Samborski, \& Mojs, 2018; Homann et al., 2012), which together with the aforementioned physical symptoms have as a consequence a negative impact on the health-related quality of life of the affected patients (Segura-Jiménez et al., 2015).

Taking into account the symptomatological variety and the amount of people affected worldwide, some studies, such as Knight (2013), have appeared trying to determine the economic impact of this disease on health systems. This study has demonstrated that the total costs (direct and indirect) per patient were $\$ 13.518, \$ 12.418$ and $\$ 9.199$ per year, in the USA, Germany and France, respectively.

On the one hand, many studies (Andrade, Sieczkowska, \& Vilarino, 2018; Chica, GonzálezGuirval, Reigal, Carranque, \& Hernández-Mendo, 2019; González, Ortín, \& Bonillo, 2011; MurilloGarcía, Villafaina, Adsuar, Gusi, \& Collado-Mateo, 2018; Sevimli, Kozanoglu, Guzel, \& Doganay, 2015; Steiner, Bigatti, \& Ang, 2015) have demonstrated that the regular practice of some controlled physical exercises (aquatic exercises, strength training, aerobic exercises among others) or participation in different intervention programs (Amutio, Franco, PérezFuentes, Gázquez, \& Mercader, 2015; Amutio et al., 2018) may alleviate many symptoms of people suffering from FM, both at a psychological and physical level. On the other hand, some studies have hypothesized that there is possible implication of myofascial tissue in what is known as "central sensitization", which refers to an increase in pain perception which is so characteristic of FM (AlonsoBlanco et al., 2011; Baek, Seok, Koo, \& Kim, 2016; Liptan, 2010).

In this sense, different studies have been conducted in order to determine the effectiveness of myofascial tissue treatment in this population. In these studies, participants are considered as passive subjects (myofascial release technique, connective tissue massage, among others) and encouraging results were obtained showing a significant improvement in the quality of life (Castro-Sánchez et al., 2019; CastroSánchez, Matarán-Peñarrocha, Arroyo-Morales, et al., 2011; Castro-Sánchez, Matarán-Peñarrocha, GraneroMolina, et al., 2011; Ekici, Bakar, Akbayrak, \& Yuksel, 2009; Liptan, Mist, Wright, Arzt, \& Jones, 2013; Toprak-Celenay et al., 2017).

Drawing on this information, the present study tries to implement an intervention programme on muscular fascia, in which patients themselves perform a selfmassage (self-myofascial release programme). Thus, each individual will be responsible for controlling the intensity of the massage every time, depending on the level of perceived pressure on each muscle group, which is being worked. In this sense, the aim of this study was to determine the effectiveness of a selfmyofascial conditioning programme on perceived widespread pain, tender points (TP) pain, depression, anxiety and sleep quality in people with FM.

\section{MATERIALS Y METHODS}

\section{Study design}

A single-blind randomized controlled trial with parallel-group study was designed. Sample size was calculated for repeated-measure analysis of variance (ANOVA), using the Visual Analogue Scale (VAS) for pain as the main parameter. For the determination of a minimal effect of $2 \mathrm{~cm}$ (Fernandes, Jennings, Nery, Pirozzi Buosi, \& Natour, 2016), a 5\% $\alpha$ error, $20 \% \beta$ error and SD $(\sigma)$ of $1.8 \mathrm{~cm}$ were established, using v7.12 (Consorci URLEC, Spain). The minimum sample for each group was determined to be 16 individuals, including $20 \%$ for possible dropouts. 


\section{Ceca et al.}

Randomisation was performed on a 1:1 ratio and based on a pre-specified computer-generated randomisation list. The random assignment of subjects to control and intervention groups was performed using block sizes of 1,2 and 3 . The whole process was carried out by two blind researchers who were external to the project. Likewise, in order to avoid potential biases, both evaluation and statistical analysis of data were performed by blinded staff members in the research group; that is to say, investigators were not aware of the assignment of subjects to the intervention or control group. Due to the characteristics of this study, it was not possible to blind participants to their treatment allocation.

\section{Participants}

A total of sixty-six participants with FM Syndrome were obtained through different associations of people affected by FM in the province of Valencia (Spain). Of these, 33 participants (age $=50.57 \pm 7.14$ ) made up the Intervention Group (IG) and 33 (age = 57.4 \pm 4.52 ) the Control Group (CG). Everyone in the sample was previously diagnosed according to the criteria proposed by the American College of Rheumatology (Wolfe et al., 1990; Wolfe et al., 2011), when they were enrolled in this study. All the participants' data were collected in the facilities of three different sports centres in this city, where the intervention programme was implemented.

The inclusion criteria were: being over 18 years of age, having a diagnosis of FM and having signed the informed consent. In addition, the following exclusion criteria were established: having a diagnosis of heart, kidney or liver failure; suffering from respiratory problems that could limit the application of the programme; having had a cardiovascular event in the previous year; having participated in any other exercise activity in the three months prior to the intervention; refusing to participate in the proposed intervention programme and refusing to sing the informed consent or being considered outliers (with scores higher than the mean plus two standard deviations). Participants were informed of the inability to participate in any other exercise program during the study.

Written informed consent was obtained from all participants prior to data collection. The present study was approved by the Research in Humans Ethics
Committee of the University of Valencia (procedure number H1427122754390), and it respects the Spanish regulations on clinical trials (Royal Decree 223/2004, dated February 6th) and the fundamental ethical principles as set forth in the Declaration of Helsinki of 1964 and its later amendments or comparable ethical standards.

\section{Procedures}

All IG participants completed a total of 40-sessions of a self-myofascial release programme conducted by a Bachelor of Science in Physical Education and Sports, with a frequency of two 50-minute sessions per week. The implemented intervention protocol was proposed by Ceca, Elvira, Guzmán and Pablos (2017).

Briefly, each session consisted of three phases. First, they began with dynamic mobility exercises in order to prepare muscles and joints for the second phase. Then, in one of the weekly sessions, participants would carry out self-myofascial conditioning exercises for the upper body, and in the following session, they would perform exercises for the lower body, adding an extra final exercise for the trapezius. According to the intervention protocol, a set of ten repetitions was performed for each muscle group. Each set lasted for about 45-60 seconds maintaining a constant pressure on a particular device, following the direction of the muscle fibres. Different devices were used, such as large and small foam balls, spiky massage balls, tennis balls and foam rollers. Each device was being added to a session depending on the pressure exerted on it by the patients, and most of all, depending on the feedback from the patients in each exercise. Finally, at the end of each session, different static stretches were performed.

Throughout the intervention programme, the intensity of the pressure exerted was increased by controlling the hardness of the material employed, the size of the material with which pressure is applied (a material with a smaller contact area will cause greater pressure intensity) and the amount of body weight resting on the material.

Participants in the CG did not receive any treatment during implementation of the study. In this case, a waiting list control was used for ethical reasons, since the primary objective of this research is to acquire a 


\section{Effects of a self-myofascial conditioning programme on fibromyalgia}

better quality of life for this special population which constitutes our passive CG.

\section{Outcomes}

In order to find out the effects of the intervention and the evaluated variables, two measurements were performed. The first one was made a week before the beginning of the training sessions (pre-intervention), while the second one was made once the sessions had finished (post-intervention). Both measurements were taken in the facilities where the intervention programme was applied.

Widespread Pain Intensity (main outcome). Widespread pain was assessed using a VAS. This measurement instrument consists of a $10-\mathrm{cm}$ horizontal line, the left end of which indicates the absence of pain, while greatest intensity is situated at the right end of the scale. Patients are instructed to mark on the line the point that represents their pain.

It is a clear, easy-to-use instrument that is very widely used. Its validity and reliability to measure pain have been well demonstrated on the academic literature (Jensen \& Karoly, 2001), particularly in special populations, including patients with FM (CastroSánchez, Matarán-Peñarrocha, Granero-Molina, et al., 2011; Uçar et al., 2015).

Tender Points (TP). The pain threshold was measured with an algometer (Wagner Force Dial FDK 20). It is a common technique used for the assessment of muscular and articular pain; it is also used for the evaluation of tender points in patients with FM (Aparicio et al., 2013; Terzi, Terzi, \& Kale, 2015), showing considerable reliability, since the interclass correlation coefficient is 0.91 , as proposed by Chesterton, Sim, Wright and Foster (2007).

Progressive pressure was applied until patients reported a change from the sensation of pressure to pain, in a range of pressure from 0 to $4 \mathrm{~kg} / \mathrm{cm} 2$.

Pressure points tested were those determined by the American College of Rheumatology (ACR): low cervical, second rib, lateral epicondyle, knee, occiput, trapezius, supraspinatus, gluteal and greater trochanter (Wolfe et al., 1990) on participants' dominant side. Two measurements were performed and the highest value was used for analysis.
Depression. A Spanish version of the Beck Depression Inventory (BDI), as it was revised by Sanz and Vázquez (1988), was used to evaluate the changes in depression levels.

It consists of 21 items which assess the intensity of the symptoms of depression. Each item has four response options presented in order of seriousness (except for item 19 which assesses whether or not there is any weight loss, and it includes five response options). Each item is scored from 0-3, so the total obtained score ranges from 0 to 63 . According to the final result, the depression severity can be determined. The standard cut-offs are as follows: 0-9: indicates minimal depression, 10-16: indicates mild depression, 17-29: indicates moderate depression, 30-63: indicates severe depression (Beck \& Steer, 1993).

Anxiety. A Spanish version of the State-Trait Anxiety Inventory (STAI) (Spielberger, Gorsuch, \& Lushene, 2008), whose reliability is similar to that of the original version, was the instrument used to quantify state and trait anxiety. This questionnaire consists of two 20-item scales for measuring state and trait anxiety. Responses are rated on a 4-point Likert scale and range from 0 (not at all) to 3 (very much). Scores on each scale ranged from $0-60$, which means a score of 60 would indicate the highest level of anxiety possible.

Sleep quality. A Spanish version of the Pittsburgh Sleep Quality Index (PSQI) was used to measure the quality of sleep (Jiménez-Genchi, MonteverdeMaldonado, Nenclares-Portocarrero, EsquivelAdame, \& de la Vega-Pacheco, 2008). The internal consistency of this version is 0.78 , and the reliability coefficient is 0.81 . The questionnaire consists of 18 items, divided into 7 components that can be scored from 0 to 3. Scores are obtained on each of seven components of sleep quality: subjective sleep quality, sleep latency, sleep duration, habitual sleep efficiency, sleep perturbations, use of hypnotic medication, and daily dysfunction. Each component is scored from 0 (symptom not present) to 3 (symptom very intense). Hence the total score (adding component scores) ranges from 0 to 21 , which means a score of 21 would indicate the worst sleep quality. 


\section{Ceca et al.}

\section{Statistical analysis}

Statistical analysis was performed using IBM SPSS Statistics V22.0 (SPSS Inc., Chicago, IL). After a descriptive analysis of all variables, a two way mixedeffect (between-within group) ANOVA with repeated measurement was applied. The Bonferroni adjustments and paired wise comparison post-hoc were used. Effect sizes $\left(\eta_{2 p}\right)$ for ANOVA were also calculated, with values of $<0.06$ considered small, < 0.14 moderate, and $\geq 0.14$ large (Cohen, 1988), and $p$ value $<0.05$ (95\% Confidence Interval) was considered statistically significant.

\section{RESULTS}

\section{Participants}

This study began in December of 2013 with 113 candidates interested in participating in the intervention programme. Among these participants, $58.4 \%$ formed the initial sample for this study, while the remaining participants $(41 \%)$ were excluded because they did not fulfil the inclusion criteria or declined participation. Finally, 66 patients were assigned randomly in two groups (CG and IG).

From the 33 participants who took part in each group, the $69.69 \%$ completed the intervention study which was carried out from January to June 2014. Thus, compliance and adherence to the programme was as high as $85 \%$ of the total number of sessions. Also, $69.69 \%$ of members of the IG completed the postintervention evaluation while only $60.60 \%$ of participants in the CG did it. There were no cases of severe adverse events or withdrawal of patients due to an adverse event during the intervention programme. Demographics of participants are shown in Table 1.

\section{Outcomes}

The final results of the variables analysed in the present study (descriptive analysis and repeated measure ANOVA) can be seen in Table 2 and Table 3. Table 2 shows the existence of statistically significant results in the main effects of ANOVA on VAS Pain $(P$ $\left.=0.003 ; \eta_{2 p}=0.197\right)$, BDI $(P=0.018 ; \eta 2 p=0.128)$, STAI-S $(P=0.003 ; \eta 2 p=0.204)$, STAI-T $(P=0.006$; $\left.\eta_{2 p}=0.174\right)$ and PSQI subscales related to "Sleep subjective quality" $\left(P=0.012 ; \eta_{2 p}=0.144\right)$, "Habitual sleep efficiency" $\left(P=0.02 ; \eta_{2 p}=0.129\right)$ and "Daily dysfunction" $\left(P<0.001 ; \eta_{2 p}=0.277\right)$. Similarly, Table 3 shows statistically significant results in the main effects for the TP located on supraspinatus $(P=0.029$; $\left.\eta_{2 p}=0.112\right)$ and greater trochanter $\left(P=0.009 ; \eta_{2 p}=\right.$ $0.153)$, as well as for the sum of all the TP evaluated $\left(P=0.036 ; \eta_{2 p}=0.105\right)$.

Furthermore, Figure 1 describes simple effects for a 2 (group) $\mathrm{x} 2$ (time) mixed analysis of variance (ANOVA). It shows statistically significant changes $(P<0.001)$ in time for IG average scores on pain and on the two subscales of two of the STAI (Figure 1B, $1 \mathrm{E}, 1 \mathrm{~F})$, as well as on the depression variable $(P<$ 0.01) (Figure 1C). There is also a significant difference in time for the CG, on the TP Sum variable (Figure 1A), while the CG members' results worsened, the IG members maintained similar ones.

Moreover, Figure 2 shows simple effect results for the TP which show a statistically significant general interaction. In this case, as shown in Figure 2A, for the "Supraspinatus" point, there can be seen an increase in the difference between CG and IG, in pre-intervention and post-intervention data. Also, for the "Great trochanter" there appear significant differences $(P<$ $0.01)$ in time between GC members who reported reduction of the pressure threshold, and IG participants who maintained the same results (Figure 2B).

Finally, Figure 3 shows simple effects for the PSQI subscales, which reveal a statistically significant interaction. In this way, it can be proven that there are significant changes in time for the IG on the averages scores of three of the internal components (Figure 3A, $3 \mathrm{~B}, 3 \mathrm{C})$, such as "Sleep subjective quality" $(P<$ $0.001)$, "Habitual sleep efficacy" $(P<0.01)$ and "Daily dysfunction" $(P<0.001)$.

\section{DISCUSSION}

The present study suggests for the first time implementing a self-myofascial release programme on psychological variables in patients affected by FM. This technique has gained relevance in the sports world in the past four or five years, but its use in the health field in order to improve the quality of life of special populations still remains limited. In the specific case of FM, we find patients with highly variable clinical manifestations and outcomes mainly due to the wide variety of symptoms and their 


\section{Effects of a self-myofascial conditioning programme on fibromyalgia}

intensity. For this reason, the purpose of this study was to evaluate the effectiveness of a self-myofascial conditioning programme on different general variables (such as pain, depression, anxiety, and quality of sleep) as these variables may have a high impact on the health-related quality of life of these people.

The review of the limited previous literature on myofascial tissue therapy, such as myofascial release techniques or connective tissue massage (applied by a physiotherapist), proved that patients with FM reported lower intensity of general pain at the end of the intervention (Castro-Sánchez et al., 2019; CastroSánchez, Matarán-Peñarrocha, Granero-Molina, et al., 2011; Ekici et al., 2009; Toprak-Celenay et al., 2017; Yuan, Matsutani, \& Marques, 2015). Additionally, healthy adult and young population who followed selfmyofascial conditioning exercises similar to ours also reported a decrease of perceived pain after finishing the programme and even 48 hours later (Cheatham, Kolber, Cain, \& Lee, 2015; Wiewelhove et al., 2019).

These studies corroborate that the pain threshold increases after brief practice applying these techniques. Along the same line of work, the results obtained in our study show a reduction of perceived general pain experienced by the IG members. The reduction of pain in patients affected by FM, after 40 sessions of intervention, might be related to the regeneration of collagen fibres, which are disposed in the appropriate direction. It might be also related to an increase of the ground substance (Van den Berg, 2013) through the stimulation of fibroblasts exerted by the mechanical tension produced during exercises (Cao, Hicks, Zein-Hammoud, \& Standley, 2015).

This action may facilitate the lessening or disappearance of intense pain perceived by the nerve endings that in many cases are located in the myofascial tissue. According to some authors, it can be directly related to "central sensitization" in FM (Alonso-Blanco et al., 2011; Ge et al., 2011).

In relation of $\mathrm{TP}$, previous studies on the same population have found different results. In particular, Castro-Sánchez, Matarán-Peñarrocha, GraneroMolina et al. (2011) found a decrease in pain in the left lower cervical, in the left and right gluteal and in the right greater trochanter, after applying myofascial release therapy. In addition, in another study by
Castro-Sánchez, Matarán-Peñarrocha, ArroyoMorales at al. (2011) using the same technique, improvements were achieved in right lower cervical, left trapezius, bilateral second rib and gluteal and right greater trochanter.

Finally, in a study conducted by Ekici et al. (2009) in which connective tissue massage was carried out, the $\mathrm{TP}$ in the trapezius was evaluated and there was an improvement on both sides. In our study, results differ from those obtained in previous research, since only the $\mathrm{CG}$ reported pain reduction in TP, supraspinatus and greater trochanter; however, measurement scores were maintained between the pre-intervention and post-intervention in the IG. Taking into account the favourable results obtained in the evaluation of pain perception, a possible explanation for these differences is that in the consulted literature, a specific treatment was done on characteristic TP of FM, while our intervention programme stimulated areas where these TP are located (as it has been explained in the description of the self-myofascial release programme) but it did not treat each tender point specifically.

Regarding the analysis of psychological variables, for example depression, some studies such as the one by Castro-Sánchez, Matarán-Peñarrocha, GraneroMolina et al. (2011), indicate that after giving myofascial release therapy to patients with FM, no significant improvement was found at the end of the intervention. On the contrary, in the line of CastroSánchez et al. (2019), results obtained in our study after applying a self-myofascial release programme proved, indeed, that there was a significant improvement in this variable.

Likewise, in relation to 'anxiety', our results also confirm a significant improvement of these levels for both scales 'state anxiety' and 'trait anxiety' as it happens in Castro-Sánchez et al. (2019). In the same line, Córdoba-Torrecilla et al. (2015) concluded that there is an inverse relationship between physical fitness and levels of anxiety in patients affected by FM, and differ from the findings by Castro-Sánchez, Matarán-Peñarrocha, Granero-Molina et al. (2011) who reported an improvement only in anxiety trait scores.

Thus, as far as psychological variables are concerned, our results are similar to most of those obtained after the application of programmes that include different 


\section{Ceca et al.}

types of physical activity such as aerobic exercise, strength-training exercise or mixed programmes. All these programmes have been proven to reduce the level of depression and anxiety in patients with FM (Andrade et al., 2018; Kelley, Kelley, \& Hootman, 2015; Murillo-García et al., 2018; Sañudo, Carrasco, de Hoyo, Figueroa, \& Saxton, 2015).

A possible explanation for the difference in the results obtained after applying myofascial techniques could be the level of socialization achieved when patients work frequently in a group of peers. Indeed, members of these programmes easily empathize with others' health conditions or the daily problems characteristic of their disease, (Beltrán-Carrillo, Tortosa-Martínez, Jennings, \& Sánchez, 2013) not to mention an increase in the levels of endorphins generated by the physical activity (Allen, 1983). In this way, our results follow the generally accepted statement that acute moderate and habitual physical exercise has beneficial effects on the response to stress and by extension on health (Moya-Albiol \& Salvador, 2001).

We should also mention the fact that our results show the improvements in PSQI component scores, after the implementation of a self-myofascial release programme. Thus, there was a reduction in the scores of the three PSQI subscales: subjective sleep quality, habitual sleep efficiency and daytime dysfunction. Similarly, Castro-Sánchez, Matarán-Peñarrocha, Granero-Molina et al. (2011) found progress in different components of the same questionnaire, but in this case, the significant improvements occurred on these two subscales: sleep latency and sleep duration. Based on what has been said, it can be accepted that the intervention carried out achieves an improvement in the quality of sleep as occurs with the application of other types of physical exercise (Aguilar-Parra et al., 2015).

This clear improvement of the symptoms after applying the intervention programme, especially in terms of physical and psychological aspects, should be taken into consideration when prescribing physical activity to this population. Considering these benefits, healthcare cost (direct and indirect) per patient with FM in Spain which is estimated to be 9.982 euros a year (Rivera, Rejas, Esteve-Vives, \& Vallejo, 2009), would be likely to be reduced. Thus, there would be no only an improvement of the quality of life of the patients, but also a reduction of the economic impact of this disease upon the healthcare system.

After the discussion of the results it is necessary to point out the limitations of our study. The first limitation inherent to this study is the impossibility of blinding participants in the allocation group. This way, only researchers and assessors could be blinded when they performed the randomized allocation and the measurements.

Another aspect of the present work which might be considered a limitation is the unilateral evaluation (dominant side) of TP as defined by ACR. This decision was consciously made; our purpose was not to establish a diagnosis of the disorder (testing the 18 $\mathrm{TP})$ since this type of diagnosis usually entails negative consequences of pain in patients within days after the measurements.

Finally, another limitation of the present work might be the fact that no evaluation was performed after the post-intervention measurements (a month later, three months later, six months later...) in order to find out if the positive effects hold over time, or if, on the contrary, they are lost in short, medium or long term.

Accordingly, the research group is aware of the need to perform similar protocols which could corroborate the results obtained in this first study based on the application of a self-myofascial release programme in people with FM, trying to minimize the limitations of the research.

In conclusion, this study gives initial evidence that the application of the self-myofascial release programme for people affected by FM, when this programme is supervised by physical activity and sport professionals, can lead to significant differences in perceived general pain; it can also alleviate state and trait anxiety, depression; moreover, it can improve subjective sleep quality, habitual sleep efficacy as well as minimize daily dysfunction. These improvements can reduce the impact of the illness at a psychological and physical level, therefore this technique could be used as a support tool which can improve the quality of life for patients. 


\section{Effects of a self-myofascial conditioning programme on fibromyalgia}

\section{PRACTICAL APPLICATIONS}

The evidences found in the present work show how a self-myofascial conditioning programme can improve some of the main FM symptoms what entails an improvement of the health-related quality of life. Likewise, the original program applied is a new tool for professionals in the field of physical activity, as a form of effective non-pharmacological treatment in the population in which this study is focused. In this way, it is possible that its application will have a direct transfer both in the area of personal training within the service sector typical of the services sector, as well as a resource within the public health system, both options located within the paradigm of physical activity and health.

\section{REFERENCES}

1. Aguilar-Parra, J. M., Gallego, J., FernándezCampoy, J. M., Pérez-Gallardo, E. R., Trigueros, R., Alías-García, A., ... Cangas, A. J. (2015). Influencia de programas de actividad física en la calidad del sueño de personas mayores de 55 años. Revista de Psicología del Deporte, 24(2), 289-295.

2. Allen, M. (1983). Activity-generated endorphins: a review of their role in sports science. Canadian Journal of Applied Sport Sciences. Journal Canadien Des Sciences Appliquées Au Sport, 8(3), 115-133.

3. Alonso-Blanco, C., Fernández-de-las-Peñas, C., Morales-Cabezas, M., Zarco-Moreno, P., Ge, H.-Y., \& Florez-García, M. (2011). Multiple active myofascial trigger points reproduce the overall spontaneous pain pattern in women with fibromyalgia and are related to widespread mechanical hypersensitivity. The Clinical Journal of Pain, 27(5), 405-413. https://doi.org/10.1097/AJP.0b013e31821011 $0 \mathrm{a}$

4. Amutio, A., Franco, C., Pérez-Fuentes, M. del C., Gázquez, J. J., \& Mercader, I. (2015). Mindfulness training for reducing anger, anxiety, and depression in fibromyalgia patients. Frontiers in Psychology, 5. https://doi.org/10.3389/fpsyg.2014.01572

5. Amutio, A., Franco, C., Sánchez-Sánchez, L. C., Pérez-Fuentes, M. C., Gázquez-Linares, J. J., Van Gordon, W., \& Molero-Jurado, M. del M. (2018). Effects of Mindfulness Training on Sleep Problems in Patients with Fibromyalgia. Frontiers in Psychology, 9. https://doi.org/10.3389/fpsyg.2018.01365

6. Andrade, A., Sieczkowska, S. M., \& Vilarino, G. T. (2018). Resistance training improves quality of life and associated factors in patients with fibromyalgia syndrome. $P M \& R$. https://doi.org/10.1016/j.pmrj.2018.09.032

7. Aparicio, V. A., Ortega, F. B., CarbonellBaeza, A., Cuevas, A. M., DelgadoFernández, M., \& Ruíz, J. (2013). Anxiety, depression and fibromyalgia pain and severity. Behavioral Psychology / Psicología Conductual: Revista Internacional Clínica y de la Salud, 21(2), 381-392.

8. Baek, S.-H., Seok, H. Y., Koo, Y. S., \& Kim, B.-J. (2016). Lengthened Cutaneous Silent Period in Fibromyalgia Suggesting Central Sensitization as a Pathogenesis. PloS One, 11(2), $\mathrm{e} 0149248$. https://doi.org/10.1371/journal.pone.0149248

9. Bartkowska, W., Samborski, W., \& Mojs, E. (2018). Cognitive functions, emotions and personality in woman with fibromyalgia. Anthropologischer Anzeiger; Bericht Uber Die Biologisch-Anthropologische Literatur, 75(4), 271-277. https://doi.org/10.1127/anthranz/2018/0900

10. Beck, A. T., \& Steer, R. A. (1993). BAI: Beck Anxiety Inventory. San Antonio, TX: Psychological Corporation.

11. Beltrán-Carrillo, V. J., Tortosa-Martínez, J., Jennings, G., \& Sánchez, E. S. (2013). Contributions of a Group-Based Exercise Program for Coping with Fibromyalgia: A Qualitative Study Giving Voice to Female 


\section{Ceca et al.}

Patients. Women \& Health, 53(6), 612-629. https://doi.org/10.1080/03630242.2013.8193 99

12. Branco, J. C., Bannwarth, B., Failde, I., Abello Carbonell, J., Blotman, F., Spaeth, M., ... Matucci-Cerinic, M. (2010). Prevalence of fibromyalgia: a survey in five European countries. Seminars in Arthritis and Rheumatism, 39(6), 448-453. https://doi.org/10.1016/j.semarthrit.2008.12.0 03

13. Cabo-Meseguer, A., Cerda-Olmedo, G., \& Luis Trillo-Mata, J. (2017). Fibromyalgia: Prevalence, epidemiologic profiles and economic costs. Medicina Clinica, 149(10), 441-448.

https://doi.org/10.1016/j.medcli.2017.06.008

14. Cao, T. V., Hicks, M. R., Zein-Hammoud, M., \& Standley, P. R. (2015). Duration and magnitude of myofascial release in 3dimensional bioengineered tendons: effects on wound healing. The Journal of The American Osteopathic Association, 115(2), 72-82. https://doi.org/10.7556/jaoa.2015.018

15. Castro-Sánchez, A. M., Garcia-Lopez, H., Fernandez-Sanchez, M., Perez-Marmol, J. M., Aguilar-Ferrandiz, M. E., Luque-Suarez, A., \& Mataran-Penarrocha, G. A. (2019). Improvement in clinical outcomes after dry needling versus myofascial release on pain pressure thresholds, quality of life, fatigue, pain intensity, quality of sleep, anxiety, and depression in patients with fibromyalgia syndrome. Disability and rehabilitation, 41(19), 2235-2246. https://doi.org/10.1080/09638288.2018.1461 259

16. Castro-Sánchez, A. M., Matarán-Peñarrocha, G. A., Granero-Molina, J., AguileraManrique, G., Quesada-Rubio, J. M., \& Moreno-Lorenzo, C. (2011). Benefits of Massage-Myofascial Release Therapy on Pain, Anxiety, Quality of Sleep, Depression, and Quality of Life in Patients with Fibromyalgia.
Complementary and Alternative Medicine: eCAM, 2011, 561753. https://doi.org/10.1155/2011/561753

17. Castro-Sánchez, A. M., Matarán-Peñarrocha, G. A., Arroyo-Morales, M., SaavedraHernández, M., Fernández-Sola, C., \& Moreno-Lorenzo, C. (2011). Effects of myofascial release techniques on pain, physical function, and postural stability in patients with fibromyalgia: a randomized controlled trial. Clinical Rehabilitation, 25(9), 800-813.

https://doi.org/10.1177/0269215511399476

18. Ceca, D., Elvira, L., Guzmán, J. F., \& Pablos, A. (2017). Benefits of a self-myofascial release program on health-related quality of life in people with fibromyalgia: a randomized controlled trial. The Journal of Sports Medicine and Physical Fitness, 57(7-8), 9931002. https://doi.org/10.23736/S00224707.17.07025-6

19. Cheatham, S. W., Kolber, M. J., Cain, M., \& Lee, M. (2015). The effects of self-myofascial release using a foam roll or roller massager on joint range of motion, muscle recovery, and performance: a systematic review. International Journal of Sports Physical Therapy, 10(6), 827-838.

20. Chesterton, L. S., Sim, J., Wright, C. C., \& Foster, N. E. (2007). Interrater reliability of algometry in measuring pressure pain thresholds in healthy humans, using multiple raters. The Clinical Journal of Pain, 23(9), 760-766.

https://doi.org/10.1097/AJP.0b013e318154b6 ae

21. Chica, A., González-Guirval, F., Reigal, R. E., Carranque, G., \& Hernández-Mendo, A. (2019). Efectos de un programa de danza española en mujeres con fibromialgia. Cuadernos de Psicología del Deporte, 19(2), 52-63. 


\section{Effects of a self-myofascial conditioning programme on fibromyalgia}

22. Cohen, J. (1988). Statistical Power Analysis for the Behavioral Sciences. Hilldale, NJ: L. Erlbaum Associates.

23. Córdoba-Torrecilla, S., Aparicio, V. A., Soriano-Maldonado, A., Estévez-López, F., Segura-Jiménez, V., Álvarez-Gallardo, I., ... Delgado-Fernández, M. (2015). Physical fitness is associated with anxiety levels in women with fibromyalgia: The al-ándalus project. Quality of Life Research: An International Journal of Quality of Life Aspects of Treatment, Care \& Rehabilitation, 25(4),

1053-1058. https://doi.org/10.1007/s11136-015-1128-y

24. Crofford, L. J. (2016). Fibromyalgia. In G. S. Firestein, R. Budd, S. E. Gabriel, I. B. McInnes, \& J. R. O'Dell (Eds.), Kelley and Firestein's Textbook of Rheumatology (pp. 768-782). Philadelphia, PA: Elsevier Health Sciences.

25. Ekici, G., Bakar, Y., Akbayrak, T., \& Yuksel, I. (2009). Comparison of manual lymph drainage therapy and connective tissue massage in women with fibromyalgia: a randomized controlled trial. Journal of Manipulative And Physiological Therapeutics, 32(2), 127-133. https://doi.org/10.1016/j.jmpt.2008.12.001

26. Fernandes, G., Jennings, F., Nery, M. V., Pirozzi-Buosi, A. L., \& Natour, J. (2016). Swimming Improves Pain and Functional Capacity of Patients with Fibromyalgia: A Randomized Controlled Trial. Archives of Physical Medicine And Rehabilitation, 97(8), 1269-1275.

https://doi.org/10.1016/j.apmr.2016.01.026

27. Ge, H.-Y., Wang, Y., Fernandez-de-lasPenas, C., Graven-Nielsen, T., DanneskioldSamsoe, B., \& Arendt-Nielsen, L. (2011). Reproduction of overall spontaneous pain pattern by manual stimulation of active myofascial trigger points in fibromyalgia patients. Arthritis Research \& Therapy, 13(2), R48. https://doi.org/10.1186/ar3289
28. González, J., Ortín, F. J., \& Bonillo, J. A. (2011). Actividad física, asistencia psicológica y niveles de ansiedad y depresión en mujeres con fibromialgia: Un estudio descriptivo. Cuadernos de Psicología del Deporte, 11(1), 59-66.

29. Homann, D., Stefanello, J. M. F., Góes, S. M., Breda, C. A., Paiva, E. dos S., \& Leite, N. (2012). Stress perception and depressive symptoms: functionality and impact on the quality of life of women with fibromyalgia. Revista Brasileira De Reumatologia, 52(3), 319-330.

30. Jensen, M. P., \& Karoly, P. (2001). Self-report scales and procedures for assessing pain in adults. In D. C. Turk \& R. Melzack (Eds.), Handbook of pain assessment (pp. 15-34). New York, NY: Guilford Press.

31. Jiménez-Genchi, A., Monteverde-Maldonado, E., Nenclares-Portocarrero, A., EsquivelAdame, G., \& de la Vega-Pacheco, A. (2008). [Reliability and factorial analysis of the Spanish version of the Pittsburg Sleep Quality Index among psychiatric patients]. Gaceta médica de México, 144(6), 491-496.

32. Kelley, G. A., Kelley, K. S., \& Hootman, J. M. (2015). Effects of exercise on depression in adults with arthritis: a systematic review with meta-analysis of randomized controlled trials. Arthritis Research \& Therapy, 17, 21-21. https://doi.org/10.1186/s13075-015-0533-5

33. Knight, T., Schaefer, C., Chandran, A., Zlateva, G., Winkelmann, A., \& Perrot, S. (2013). Health-resource use and costs associated with fibromyalgia in France, Germany, and the United States. Clinicoeconomics And Outcomes Research: CEOR, 5, 171-180. https://doi.org/10.2147/CEOR.S41111

34. Liptan, G. L. (2010). Fascia: A missing link in our understanding of the pathology of fibromyalgia. Journal of bodywork and movement therapies, 14(1), 3-12. https://doi.org/10.1016/j.jbmt.2009.08.003 


\section{Ceca et al.}

35. Liptan, G., Mist, S., Wright, C., Arzt, A., \& Jones, K. D. (2013). A pilot study of myofascial release therapy compared to Swedish massage in Fibromyalgia. Journal of bodywork and movement therapies, 17(3), 365-370.

https://doi.org/10.1016/j.jbmt.2012.11.010

36. Mas, A. J., Carmona, L., Valverde, M., Ribas, B., \& EPISER Study Group. (2008). Prevalence and impact of fibromyalgia on function and quality of life in individuals from the general population: results from a nationwide study in Spain. Clinical and Experimental Rheumatology, 26(4), 519-526.

37. Moya-Albiol, L., \& Salvador, A. (2001). Efectos del ejercicio físico agudo sobre la respuesta psicofisiológica al estrés: papel modulador de la condición física. Revista de Psicología del Deporte, 10(1), 35-48.

38. Murillo-García, Á., Villafaina, S., Adsuar, J. C., Gusi, N., \& Collado-Mateo, D. (2018). Effects of Dance on Pain in Patients with Fibromyalgia: A Systematic Review and Meta-Analysis. Evidence-Based Complementary And Alternative Medicine: Ecam, 2018, 8709748-8709748. https://doi.org/10.1155/2018/8709748

39. Rivera, J., Rejas, J., Esteve-Vives, J., \& Vallejo, M. A. (2009). Resource utilisation and health care costs in patients diagnosed with fibromyalgia in Spain. Clinical And Experimental Rheumatology, 27(5 Suppl 56), S39-S45.

40. Sanz, J., \& Vázquez, C. (1988). Fiabilidad, validez y datos normativos del inventario para la depresión de Beck. Psicothema, 10(2), 303318.

41. Sañudo, B., Carrasco, L., de Hoyo, M., Figueroa, A., \& Saxton, J. M. (2015). Vagal modulation and symptomatology following a 6-month aerobic exercise program for women with fibromyalgia. Clinical And Experimental Rheumatology, 33(1 Suppl 88), S41-S45.
42. Segura-Jiménez, V., Álvarez-Gallardo, I. C., Carbonell-Baeza, A., Aparicio, V. A., Ortega, F. B., Casimiro, A. J., \& Delgado-Fernández, M. (2015). Fibromyalgia has a larger impact on physical health than on psychological health, yet both are markedly affected: the alÁndalus project. Seminars In Arthritis And Rheumatism, 44(5), 563-570. https://doi.org/10.1016/j.semarthrit.2014.09.0 10

43. Sevimli, D., Kozanoglu, E., Guzel, R., \& Doganay, A. (2015). The effects of aquatic, isometric strength-stretching and aerobic exercise on physical and psychological parameters of female patients with fibromyalgia syndrome. Journal Of Physical Therapy Science, 27(6), 1781-1786. https://doi.org/10.1589/jpts.27.1781

44. Spielberger, C. D., Gorsuch, R. L., \& Lushene, R. E. (2008). STAI, Cuestionario de Ansiedad Estado-Rasgo. Madrid: TEA Ediciones, S.A.

45. Steiner, J. L., Bigatti, S. M., \& Ang, D. C. (2015). Trajectory of change in pain, depression, and physical functioning after physical activity adoption in fibromyalgia. Journal of Health Psychology, 20(7), 931941.

https://doi.org/10.1177/1359105313504234

46. Terzi, H., Terzi, R., \& Kale, A. (2015). The relationship between fibromyalgia and pressure pain threshold in patients with dyspareunia. Pain Research \& Management, 20(3), 137-140. https://doi.org/10.1155/2015/302404

47. Toprak-Celenay, S., Anaforoglu-Kulunkoglu, B., Yasa, M. E., Sahbaz-Pirincci, C., Un Yildirim, N., Kucuksahin, O., ... Akkus, S. (2017). A comparison of the effects of exercises plus connective tissue massage to exercises alone in women with fibromyalgia syndrome: a randomized controlled trial. Rheumatology International, 37(11), 1799- 


\section{Effects of a self-myofascial conditioning programme on fibromyalgia}

1806. https://doi.org/10.1007/s00296-0173805-3

48. Uçar, M., Sarp, Ü., Karaaslan, Ö., Gül, A. I., Tanik, N., \& Arik, H. O. (2015). Health anxiety and depression in patients with fibromyalgia syndrome. The Journal of International Medical Research, 43(5), 679685.https://doi.org/10.1177/03000605155875 78

49. Van den Berg, F. (2013). Extracellular matrix. In Fascia: The Tensional Network of the Human Body (pp. 165-170). London, UK: Elsevier Health Sciences. https://doi.org/10.1016/B978-0-7020-3425$1.00058-1$

50. Wiewelhove, T., Doeweling, A., Schneider, C., Hottenrott, L., Meyer, T., Kellmann, M., ... Ferrauti, A. (2019). A Meta-Analysis of the Effects of Foam Rolling on Performance and Recovery. Frontiers in Physiology, 10, 376. https://doi.org/10.3389/fphys.2019.00376

51. Wolfe, F., Smythe, H. A., Yunus, M. B., Bennett, R. M., Bombardier, C., Goldenberg,
D. L., ... et. al. (1990). The American College of Rheumatology 1990 Criteria for the Classification of Fibromyalgia. Report of the Multicenter Criteria Committee. Arthritis And Rheumatism, 33(2), 160-172. https://doi.org/10.1002/art.1780330203

52. Wolfe, F., Clauw, D. J., Fitzcharles, M.-A., Goldenberg, D. L., Häuser, W., Katz, R. S., ... Winfield, J. B. (2011). Fibromyalgia criteria and severity scales for clinical and epidemiological studies: a modification of the ACR Preliminary Diagnostic Criteria for Fibromyalgia. The Journal of Rheumatology, $38(6)$,

1113-1122. https://doi.org/10.3899/jrheum.100594

53. Yuan, S. L. K., Matsutani, L. A., \& Marques, A. P. (2015). Effectiveness of different styles of massage therapy in fibromyalgia: A systematic review and meta-analysis. Manual Therapy, 20(2), 257-264. https://doi.org/10.1016/j.math.2014.09.003 


\section{Ceca et al.}

Table 1

Demographic data of the sample.

\begin{tabular}{lccc}
\hline \multicolumn{1}{c}{ Variable } & $\begin{array}{c}\text { IG } \\
(\mathbf{n = 2 3})\end{array}$ & $\begin{array}{c}\text { CG } \\
(\mathbf{n = 2 0})\end{array}$ & $\begin{array}{c}\text { Total } \\
\mathbf{( N = 4 3 )}\end{array}$ \\
\hline Gender (female), $\mathrm{n}(\%)$ & $20(86.95)$ & $19(95)$ & $39(90.69)$ \\
Ethnicity White, $\mathrm{n}(\%)$ & $23(100)$ & $20(100)$ & $43(100)$ \\
Diseases & & & \\
Back pain, n(\%) & $14(60.9)$ & $11(55)$ & $25(58.1)$ \\
Depression, $\mathrm{n}(\%)$ & $16(69.6)$ & $14(70)$ & $30(69.8)$ \\
Insomnia, n(\%) & $3(13)$ & $7(35)$ & $10(23.3)$ \\
Osteoarthritis, $\mathrm{n}(\%)$ & $8(34.8)$ & $10(50)$ & $18(41.9)$ \\
Brain injury/cognitive impairment, $\mathrm{n}(\%)$ & $3(13)$ & $2(9.5)$ & $5(11.6)$ \\
Chronic fatigue, $\mathrm{n}(\%)$ & $8(34.8)$ & $4(20)$ & $12(27.9)$ \\
Anxiety, n(\%) & $9(39.1)$ & $11(55)$ & $20(46.5)$ \\
Hypothyroidism, $\mathrm{n}(\%)$ & $3(13)$ & $3(15)$ & $6(14)$ \\
Osteoporosis, $\mathrm{n}(\%)$ & $3(13)$ & $1(5)$ & $4(9.3)$ \\
Irritable colon, $\mathrm{n}(\%)$ & $4(17.4)$ & $0(0)$ & $4(9.3)$ \\
\hline
\end{tabular}

Note: data are expressed with $\mathrm{n}$ and $\%$. $\mathrm{n}$-values are the number of subjects who meet the condition. IG= Intervention group; $\mathrm{CG}=$ Control group. $* P<0.05$. $P$-values were calculated using $\mathrm{X}^{2}$ test. 
Effects of a self-myofascial conditioning programme on fibromyalgia

Table 2

Values obtained in the descriptive analysis and results of the time x group comparative analysis for pain, depression, sleep quality and anxiety.

\begin{tabular}{|c|c|c|c|c|c|c|c|c|}
\hline \multirow[b]{2}{*}{ Variable } & \multirow[b]{2}{*}{ Group } & \multirow[b]{2}{*}{$\mathbf{N}$} & \multirow{2}{*}{$\begin{array}{c}\begin{array}{c}\text { Pre- } \\
\text { Intervention }\end{array} \\
\text { Mean (SD) }\end{array}$} & \multirow{2}{*}{$\begin{array}{c}\begin{array}{c}\text { Post- } \\
\text { intervention }\end{array} \\
\text { Mean (SD) }\end{array}$} & \multirow{2}{*}{$\begin{array}{c}\begin{array}{c}\text { Pre-Post intervention } \\
\text { difference }\end{array} \\
\text { Mean }(95 \% \mathrm{CI})\end{array}$} & \multicolumn{3}{|c|}{ Between-group interaction } \\
\hline & & & & & & $\begin{array}{c}F- \\
\text { value }\end{array}$ & $\begin{array}{c}P- \\
\text { value }\end{array}$ & $\eta^{2} \mathbf{p}$ \\
\hline \multirow{2}{*}{ VAS Pain } & IG & 23 & $5.61(1.73)$ & $4.00(1.62)$ & $1.609(0.867$ to 2.351$)$ & 10.061 & $0.003^{*}$ & 0.197 \\
\hline & CG & 20 & $6.45(1.50)$ & $6.55(1.99)$ & $-0.100(-0.896$ to 0.696$)$ & & & \\
\hline \multirow{2}{*}{ BDI } & IG & 23 & $22.83(8.11)$ & $17.96(9.29)$ & $4.870(1.551$ to 8.188$)$ & 6.038 & $0.018^{*}$ & 0.128 \\
\hline & CG & 20 & $22.65(9.12)$ & $23.70(8.05)$ & $-1.05(-4.608$ to 2.508$)$ & & & \\
\hline \multirow{2}{*}{ PSQI Total Score } & IG & 22 & $14.27(4.07)$ & $12.95(4.42)$ & $1.318(-0.177$ to 2.813$)$ & 3.373 & 0.074 & 0.078 \\
\hline & CG & 20 & $13.80(3.1)$ & $14.45(3.46)$ & $-0.65(-2.218$ to 0.918$)$ & & & \\
\hline \multirow{2}{*}{ SSQ } & IG & 23 & $2.26(0.86)$ & $1.65(1.03)$ & $0.609(0.29$ to 0.927$)$ & 6.922 & $0.012 *$ & 0.144 \\
\hline & CG & 20 & $2.25(0.64)$ & $2.25(0.72)$ & $0.61(0.68$ to 0.53$)$ & & & \\
\hline \multirow{2}{*}{ SL } & IG & 23 & $2(0.98)$ & $1.82(1.05)$ & $0.182(-0.231$ to 0.595$)$ & 1.282 & 0.264 & 0.032 \\
\hline & CG & 20 & $2.26(0.99)$ & $2.42(0.9)$ & $-0.158(-0.602$ to 0.287$)$ & & & \\
\hline \multirow{2}{*}{ SDU } & IG & 23 & $1.64(1.09)$ & $1.55(0.8)$ & $0.091(-0.258$ to 0.44$)$ & 1.955 & 0.170 & 0.048 \\
\hline & CG & 20 & $1.53(1.12)$ & $1.79(1.13)$ & $-0.263(-0.638$ to 0.112$)$ & & & \\
\hline \multirow{2}{*}{ HSE } & IG & 23 & $1.70(1.3)$ & $0.87(0.69)$ & $0.826(0.335$ to 1.317$)$ & 5.923 & $0.020^{*}$ & 0.129 \\
\hline & CG & 20 & $1.58(1.07)$ & $1.63(1.17)$ & $-0.053(-0.487$ to 0.593$)$ & & & \\
\hline & IG & 23 & $2.26(0.75)$ & $2.04(0.77)$ & $0.217(-0.076$ to 0.511$)$ & 1.041 & 0.314 & 0.025 \\
\hline & CG & 20 & $2.2(0.62)$ & $2.2(0.62)$ & $0.22(0.23$ to 0.21$)$ & & & \\
\hline \multirow{2}{*}{ UHM } & IG & 23 & $2.39(1.16)$ & $2.35(1.03)$ & $0.043(-0.293$ to 0.380$)$ & 0.411 & 0.525 & 0.010 \\
\hline & CG & 20 & $2.45(1.1)$ & $2.25(1.25)$ & $0.2(-0.161$ to 0.561$)$ & & & \\
\hline \multirow[t]{2}{*}{ DD } & IG & 23 & $2.39(0.84)$ & $1.65(0.89)$ & $0.739(0.465$ to 1.013$)$ & 15.711 & $<0.001 *$ & 0.277 \\
\hline & CG & 20 & $2.15(0.81)$ & $2.20(0.89)$ & $-0.05(-0.244$ to 0.344$)$ & & & \\
\hline \multirow{2}{*}{ STAI-S } & IG & 22 & $33.14(11.31)$ & $23.05(9.35)$ & $10.091(6.127$ to 14.055$)$ & 9.970 & $0.003 *$ & 0.204 \\
\hline & CG & 19 & $33.11(9.83)$ & $32.11(9.92)$ & $1(-3.266$ to 5.266$)$ & & & \\
\hline \multirow{2}{*}{ STAI-T } & IG & 22 & $34.91(8.90)$ & $28.45(10.31)$ & $6.455(3.279$ to 9.630$)$ & 8.416 & $0.006^{*}$ & 0.174 \\
\hline & CG & 20 & $32.75(8.90)$ & $32.90(9.81)$ & $-0.150(-3.180$ to 3.480$)$ & & & \\
\hline
\end{tabular}

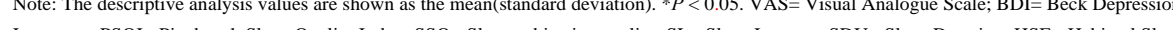

Inventory; PSQI= Pittsburgh Sleep Quality Index; SSQ= Sleep subjective quality; SL= Sleep Latency; SDU= Sleep Duration; HSE= Habitual Sleep

Efficiency; SP= Sleep perturbations; UHM= Use of hypnotic medication; DD= Daily dysfunction; STAI-S= State-Trait Anxiety Inventory State-Scale

STAI-T= State-Trait Anxiety Inventory Trait-Scale; Cl= Confidence Interval; $\eta_{\mathrm{p}}^{2}=$ effect size, eta squared; IG= Intervention group; $\mathrm{CG}=$ Control group

Thresholds for $\eta_{\mathrm{p}}^{2}:<0.06$ small, $<0.14$ moderate and $\geq 0.14$ large. 


\section{Ceca et al.}

Table 3

Values obtained in the descriptive analysis and results of the time x group comparative analysis for the Tender Points analysed.

\begin{tabular}{|c|c|c|c|c|c|c|c|c|}
\hline \multirow[b]{2}{*}{ Variable } & \multirow[b]{2}{*}{ Group } & \multirow[b]{2}{*}{$\mathbf{N}$} & \multirow{2}{*}{$\begin{array}{c}\begin{array}{c}\text { Pre- } \\
\text { Intervention }\end{array} \\
\text { Mean(SD) }\end{array}$} & \multirow{2}{*}{$\begin{array}{c}\begin{array}{c}\text { Post- } \\
\text { Intervention }\end{array} \\
\text { Mean(SD) }\end{array}$} & \multirow{2}{*}{$\begin{array}{c}\begin{array}{c}\text { Pre-Post intervention } \\
\text { difference }\end{array} \\
\text { Mean }(95 \% \mathrm{CI})\end{array}$} & \multicolumn{3}{|c|}{ Between-group interaction } \\
\hline & & & & & & $F$-value & $P$-value & $\eta^{2}$ \\
\hline \multirow{2}{*}{ Low Cervical } & $\overline{I G}$ & 23 & $0.48(0.48)$ & $0.43(0.51)$ & $0.057(-0.161$ to 0.274$)$ & 0.768 & 0.386 & 0.018 \\
\hline & CG & 20 & $0.29(0.41)$ & $0.1(0.02)$ & $0.195(-0.038$ to 0.428$)$ & & & \\
\hline \multirow{2}{*}{ Second Rib } & IG & 23 & $1.13(0.56)$ & $0.68(0.64)$ & $0.452(0.221$ to 0.684$)$ & 1.241 & 0.272 & 0.029 \\
\hline & $\mathrm{CG}$ & 20 & $0.41(0.48)$ & $0.14(0.20)$ & $0.265(0.017$ to 0.513$)$ & & & \\
\hline Lateral & IG & 23 & $1.37(0.98)$ & $1.14(0.89)$ & $0.239(-0.133$ to 0.611$)$ & 0.001 & 0.973 & 0.000 \\
\hline Epicondyle & CG & 20 & $0.53(0.63)$ & $0.30(0.43)$ & $0.23(-0.169$ to 0.629$)$ & & & \\
\hline \multirow{2}{*}{ Knee } & IG & 23 & $1.27(0.75)$ & $1.37(0.84)$ & $-0.109(-0.447$ to 0.229$)$ & 1.903 & 0.175 & 0.044 \\
\hline & CG & 20 & $0.54(0.71)$ & $0.31(0.44)$ & $0.23(-0.133$ to 0.593$)$ & & & \\
\hline \multirow{2}{*}{ Occiput } & IG & 23 & $1.02(0.69)$ & $0.99(0.71)$ & $0.03(-0.276$ to 0.337$)$ & 1.750 & 0.193 & 0.041 \\
\hline & CG & 20 & $0.64(0.64)$ & $0.31(0.45)$ & $0.325(-0.004$ to 0.654$)$ & & & \\
\hline \multirow{2}{*}{ Trapezius } & IG & 23 & $1.09(0.82)$ & $1.25(0.73)$ & $-0.161(-0.464$ to 0.143$)$ & 2.682 & 0.109 & 0.061 \\
\hline & CG & 20 & $0.78(0.68)$ & $0.58(0.57)$ & $0.2(-0.125$ to 0.525$)$ & & & \\
\hline \multirow{2}{*}{ Supraspinatus } & IG & 23 & $1.55(0.72)$ & $1.79(0.93)$ & $-0.235(-0.541$ to 0.072$)$ & 5.147 & $0.029^{*}$ & 0.112 \\
\hline & CG & 20 & $0.77(0.66)$ & $0.50(0.59)$ & $0.27(-0.059$ to 0.599$)$ & & & \\
\hline \multirow{2}{*}{ Gluteal } & IG & 23 & $1.63(0.85)$ & $1.75(0.89)$ & $-0.117(-0.435$ to 0.2$)$ & 2.603 & 0.114 & 0.06 \\
\hline & CG & 20 & $0.78(0.83)$ & $0.52(0.62)$ & $0.255(-0.086$ to 0.596$)$ & & & \\
\hline Greater & IG & 23 & $1.59(0.68)$ & $1.74(0.95)$ & $-0.157(-0.446$ to 0.133$)$ & 7.407 & $0.009 *$ & 0.153 \\
\hline Trochanter & CG & 20 & $0.90(0.80)$ & $0.48(0.55)$ & $0.415(0.105$ to 0.725$)$ & & & \\
\hline \multirow[t]{2}{*}{ TP Sum } & IG & 23 & $11.13(5.59)$ & $11.13(5.85)$ & $0.0(-1.577$ to 1.577$)$ & 4.685 & $0.036^{*}$ & 0.105 \\
\hline & CG & 19 & $5.86(4.48)$ & $3.35(2.45)$ & $2.511(0.776$ to 4.245$)$ & & & \\
\hline
\end{tabular}




\section{Effects of a self-myofascial conditioning programme on fibromyalgia}
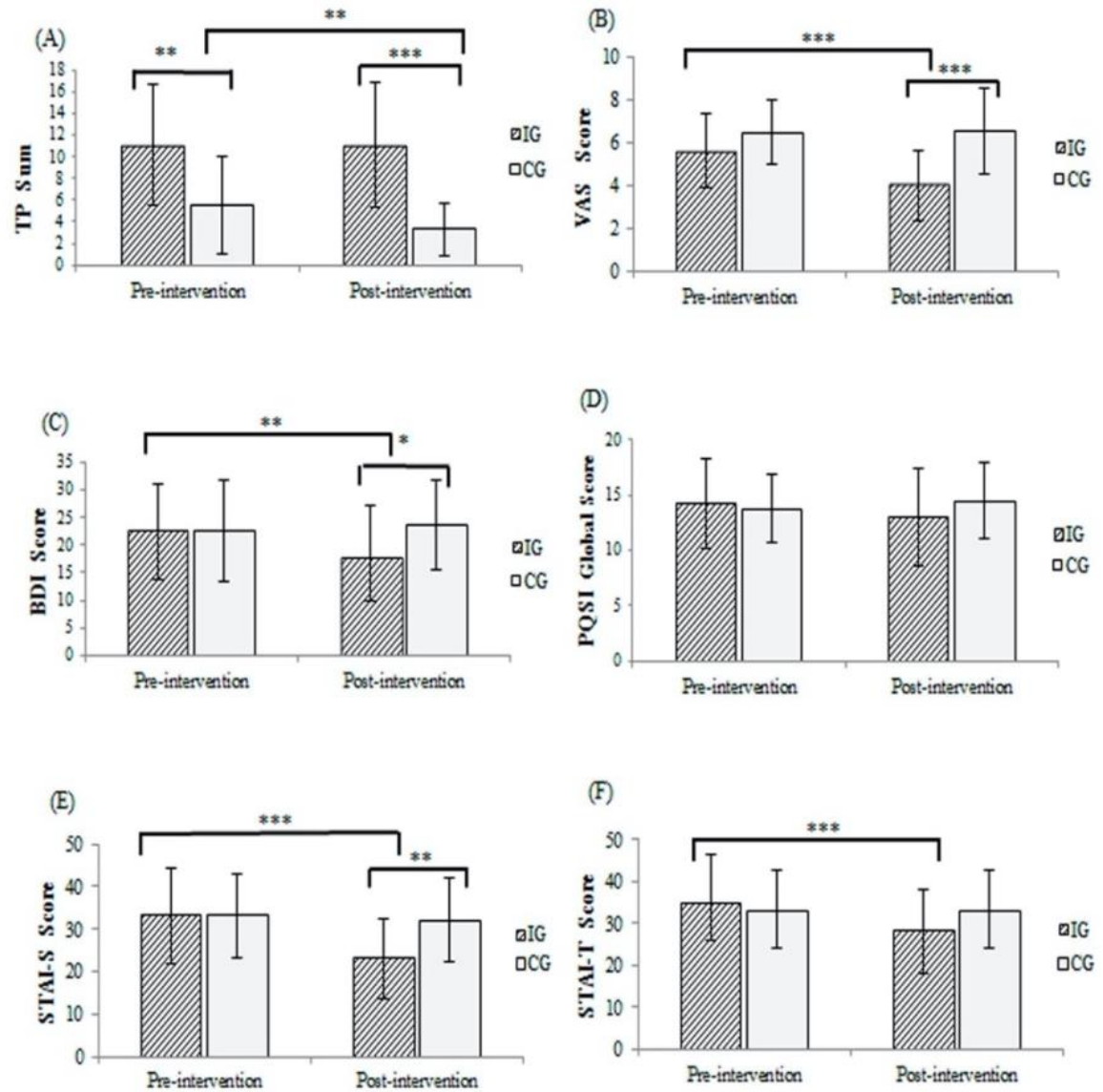

Figure 1. Simple effects of mixed analysis of variance for the main variables of the study. VAS = Visual Analogue Scale; BDI = Beck Depression Inventory; PSQI $=$ Pittsburgh Sleep Quality Index; STAI-S = State scale of the State-Trait Anxiety Inventory; STAI-T = Trait scale of the State-Trait Anxiety Inventory. Significance level: *** $\mathrm{P}<0.001 ; * * \mathrm{P}<0.01 ; * \mathrm{P}<0.05$.

$\mathrm{P}<0.001 ; * * \mathrm{P}<0.01 ; * \mathrm{P}<0.05$.




\section{Ceca et al.}
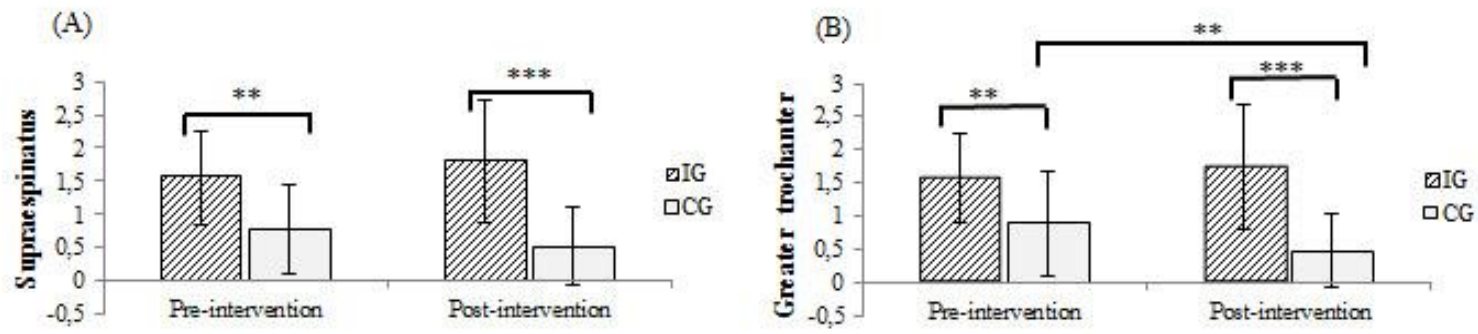

Figure 2. Simple effects of mixed analysis of variance for the TP that show a statistical significant interaction. Significance level: $* * * \mathrm{P}<0.001 ; * * \mathrm{P}<0.01 ; * \mathrm{P}<0.05$.

Oociedad


Effects of a self-myofascial conditioning programme on fibromyalgia
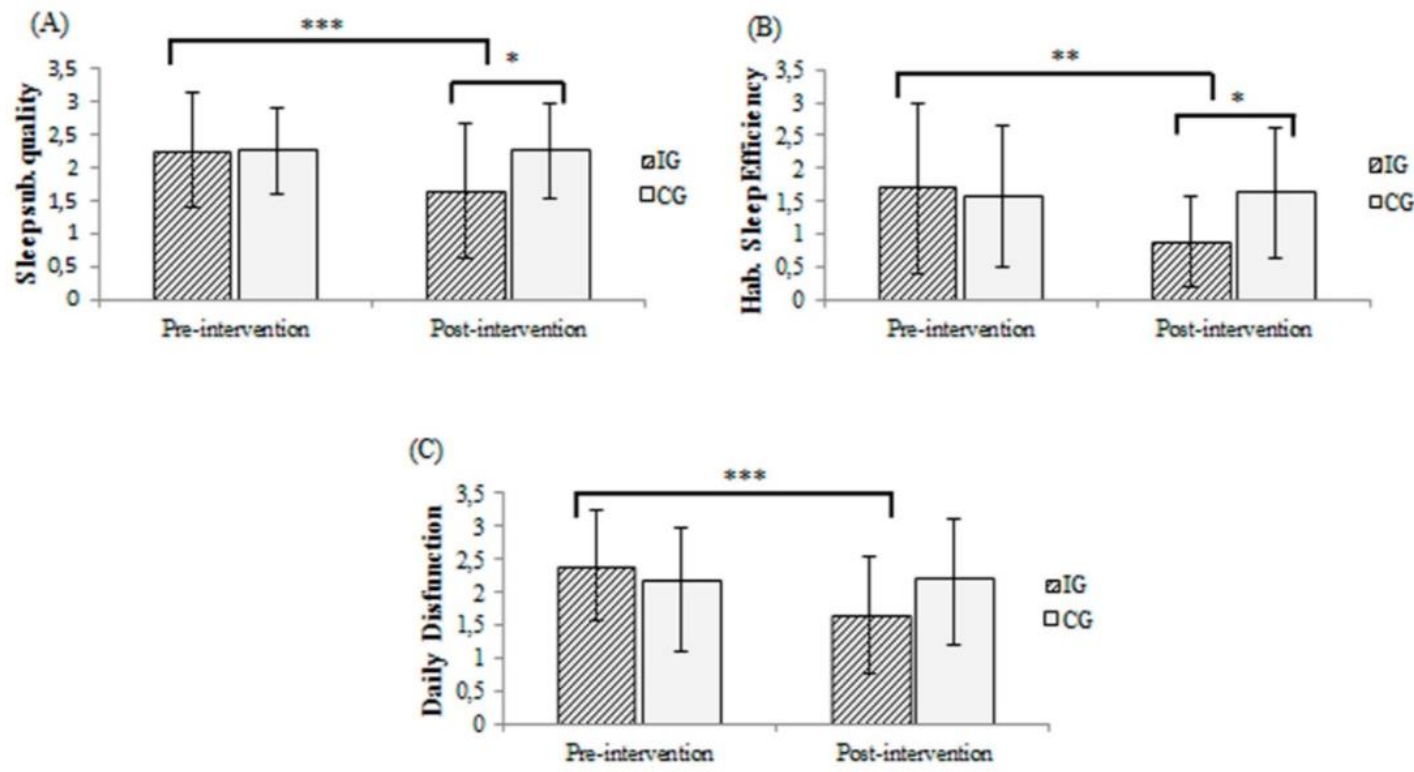

Figure 3. Simple effects of mixed analysis of variance for the components of PSQI that present a statistical significant interaction. Significance level: $* * * \mathrm{P}<0.001 ; * * \mathrm{P}<$ $0.01 ; * \mathrm{P}<0.05$ 